\title{
An Analysis of the Innovation Path of Journalism and Communication Education in Chinese Universities in the Era of Media Convergence
}

\author{
Min Wang \\ Guizhou Minzu University, Guiyang, China \\ Email: wx19999@outlook.com
}

How to cite this paper: Wang, M. (2020). An Analysis of the Innovation Path of Journalism and Communication Education in Chinese Universities in the Era of Media Convergence. Creative Education, 11, 2458-2466.

https://doi.org/10.4236/ce.2020.1111180

Received: November 2, 2020

Accepted: November 24, 2020

Published: November 27, 2020

Copyright $\odot 2020$ by author(s) and Scientific Research Publishing Inc. This work is licensed under the Creative Commons Attribution International License (CC BY 4.0).

http://creativecommons.org/licenses/by/4.0/

\begin{abstract}
Based on the new ecological media integration formed by new media technology, China's journalism education has begun to explore innovative practices of training concepts and training models. This article, while briefly sorting out these innovation paths, puts forward its own views. The new ecological media integration spawned by Internet technology has put forward brand-new requirements for journalism and communication education in Chinese universities. Facing the changes in demand for news media talents by media convergence, journalism and communication education in Chinese colleges and universities, which focuses on cultivating traditional media talents, need to update concepts, innovate methods, improve systems, and change traditional teaching models in order to cultivate journalism and communication talents needed in the media convergence era.
\end{abstract}

\section{Keywords}

Media Convergence Era, Journalism and Communication Education, Innovation Path

\section{Update of the Concept of Journalism Education}

The development of new media technology has continuously put forward higher requirements on the abilities of practitioners due to unique timeliness of journalism and communication itself. This means that Chinese colleges and universities must keep up with the trend of the times in media education, introduce the 
latest media technology, communication concepts and content to students, and guide and help students develop forward-looking perspectives and multiple thinking.

\subsection{The Transition of Courses from Online to Offline}

It is worth noting that among many colleges and universities in China offering journalism and communication majors, a considerable number of them have the problem of "talking on paper". The curriculum is limited to teaching traditional history and traditional theories, and the proportion of the teachers pioneering the use of new media is not optimistic. Firstly, teachers have the responsibility to actively use new media platforms and actively interact with students through Weibo, Zhihu, WeChat and other platforms to cultivate students' new media thinking; secondly, teachers should introduce the development and operation methods of new media to students. By inviting industry leaders to make lectures, students are exposed to the latest concepts; in addition, tasks in subject assignments and examination methods can be the operation of official accounts, UI design, and survey data of new media, other methods through jumping out of traditional thesis and test papers to train students to become cutting-edge talents that meet the needs of the times and the market (Yin \& Zhang, 2020).

\subsection{Change in Roles from the Leader to the Participant}

For the fast-developing and short-history new media era, while teachers play a good role as a guide, they should also participate in exploration with their students and become experiencers and users of the latest media. Teachers' ideas should be changed, and the teaching contents of new media and news practice should not be reduced on the grounds of "lack of experience". At present, various universities have established new media bases and laboratories one after another, adopting the form of "teacher guidance and joint cooperation" to conduct organized, scaled, and planned exploration of the ever-changing media. In this form, the main task of teachers is to grasp the direction of practice and provide relevant experience (Zheng, 2017). They should take part in researching and learning the unknown areas of new media.

\subsection{The Transformation of Teaching Direction from Arts to Science}

With the development of the Internet, new media, and big data, the major of journalism and communication is no longer confined to traditional categories that belong to the field of literature, instead, which gradually begin to rely on Internet technology, big data algorithms and other science and engineering thinking. Schools should change their ideological concepts, strengthen the joint cooperation between information engineering, Internet and other majors and the major of journalism and communication. Analyzing and obtaining the latest data, user habits and their development trends from the dimension of algorithms by establishing subject laboratories (Tang \& Zhen, 2017). In the curricu- 
lum, teachers should also introduce data journalism related content. While cultivating students' comprehensive ability, it also helps to cultivate journalism students' logical thinking and rational thinking.

The transformation of educational philosophy is not an easy task overnight. It is based on the continuous updating and upgrading of the experience and vision of educators. It also requires schools to have sufficient funds and ability to carry out educational reforms. The transition from traditional teaching models to new educational concepts requires the long-term and joint efforts of all educators. When a comprehensive new media practice is not possible for the time being, educators should first focus on guiding students' creativity and curiosity, and avoid cultivating the subject into a low-level subject that only requires memorization and papers writing. Relevant colleges that set up journalism and communication should actively apply for funds and assistance, try boldly, and be creative.

\section{Emphasis on Professionalism and Innovative Ideas}

Education of Journalism and communication in colleges and universities must first emphasize professionalism and dedication (Chen, 2013). The important aspect of the media industry that is different from other production industries is that media products not only have economic benefits, but more importantly, they have social benefits. Only when colleges and universities cultivate compound professionals with professionalism in journalism, can they adapt to the new dynamics and trends of the development of the journalism industry, and play an important positive role in the construction of the socialist market economy. This requires two Spirits: First, have a good professional ethics and a strong sense of social responsibility. This is the bottom line of the practitioner in Journalism and communication. The second is to have teamwork, innovative spirit and communication skills. These are extremely important connotations of high-quality talents in the 21 st century. In response to the new requirements of innovative and applied talents in journalism and communication, the education of journalism and communication in colleges and universities should pay attention to cultivating students' innovative thinking as well as coordination and communication skills, and improve the overall humanities Quality, strengthen the establishment of humanistic quality knowledge courses, and achieve "wide-calibre" and "thick foundation" (Qiang et al., 2020). Only in this way can we cultivate professionals in the major who can meet the needs of the culture of socialist market economy and have the main characteristics of practicality, complexity, and innovation.

\section{Improve the Cross-Media Curriculum System}

Two types of new talents are needed after the integration of media: "high-level management talents who know how to integrate communication planning and versatile journalists and editors who can use a variety of technical tools." "Media 
convergence reporters" can write texts published on different terminals and can shoot and make video news (Wang, 2018). Some well-known journalism schools in the United States have already opened a major in "Convergence Journalism". Many newspapers and TV stations have also begun to select their own reporters, arranged pilot training of convergent media reporters, who can write, deal with texts, photos and videos, and understand the characteristics and rules of Internet communication.

To break the curriculum system set up according to the boundaries of media forms, a "platform + module" operation model can be adopted, including general education; subject major education platform; professional basic education platform; professional modules. "The major orientation and curriculum systems set according to the type of media can no longer meet the actual needs of media development" (Bai, 2020). It is necessary to expand the knowledge and humanistic literacy of students. The first journalism school in the world, the University of Missouri School of Journalism, whose undergraduate study attaches great importance to general education in humanities. Professional courses should break the boundaries of media. After mastering the basic methods of writing, editing, and commenting, students in journalism also have knowledge and skills in various media such as broadcasting, network, and video. In this way, achieving mastery through a comprehensive study of the subject can lay the foundation for "convergent journalists." The essence of "media convergence" education and teaching is to break through the traditional practice of setting professional directions and curriculum systems according to various media types (Wang, 2018). Appropriate improvements should also be made in education methods. An important problem in traditional Chinese education is that there is little interaction between teachers and students. It is necessary to change the phenomenon of teacher-oriented and student-assisted classrooms. The purpose of teaching methods such as case method, project method, and inquiry method is to mobilize students' initiative and operational ability.

\section{Promote Innovation in the Evaluation System}

To build a diversified and innovative evaluation system for teachers and students, we can take consideration from two aspects: the student and the teacher. The evaluation of journalism and communication teachers should construct a new evaluation system for teaching and research. Nowadays, Chinese universities attach great importance to the number of academic papers published by teachers, and publishing a paper in a core journal has a considerable degree of material reward. However, journalism teachers have their particularities that they should be encouraged to connect with practical activities of the industry's journalism and communication. If the published news works or photographic pictures are recognized by the industry, which should be regarded as academic papers and should be rewarded. From a certain perspective, teachers of the major of journalism and communication, publishing news works, pictures or videos 
in the media should be more valuable and more realistic than academic papers. "Teachers bringing students to practice in the media should be converted into a workload equivalent to classroom teaching; when teachers carry out news planning during practical teaching, those who are adopted by the media and have a good response after reporting should be rewarded as results that are as important as scientific research; teachers and students who open columns in the media and publish reports or comments with good results should be rewarded as teaching achievements" (Guoke et al., 2016). If these problems can be solved by education, schools and other relevant departments, then the enthusiasm of teachers in this subject will be brought into play Come out, this will definitely benefit the journalism and communication discipline with practical characteristics, and will eventually promote the development of the major journalism and communication, and bring benefits to the training of journalism and communication talents.

To improve the appraisal methods of students' dissertations, we can use industry-recognized research reports, in-depth reports, communications, film and television works, photographic works, online videos, etc. to replace graduation thesis. The examination mode for students majoring in journalism and communication should also be further broken. Those research reports, news works, planning schemes, awards, etc. should all be included in the new assessment system. The world-renowned school of journalism and communication adopts a flexible approach to student dissertations. "A postgraduate of Columbia Journalism School can write an in-depth report of more than 6000 words or produce a 30-minute TV in-depth report program as a Master's thesis, and there is no requirement to publish or broadcast, but only need to be recognized by the instructor" (He, 2017). Why not a graduate of Chinese journalism?

\section{Improve Teachers' "Practical” Ability}

The faculty is an important resource in the education and teaching process. However, the practical experience and ability of teachers in many universities in many countries are much more emphasized. For example, the School of Journalism of the University of Missouri in the United States require teachers have relevant experience in all professional practical courses. Most of them are mostly media professionals and named editors. However, in domestic "non-doctors, no entrance", academic qualifications rather than practical experience of teachers are often valued. The author believes that due to the application characteristics of the mafor of journalism and communication, the introduction of teachers must break the phenomenon of "non-doctors, no entrance". To rationally introduce or hire some talents with practical experience, it is necessary to "steadily and boldly absorb industry elites", "teachers in Journalism need to break through their professional limitations, establish a cross-media, interdisciplinary, and cross-cultural thinking perspective. Under this premise, they need to adjust their knowledge structures" (Zheng, 2017). Teachers must continue to enrich 
and broaden their knowledge structures and conduct practical and business training to improve business capabilities. Of course, schools can take the approach of "inviting in" and "going out".

Actively exploring an international school-running model, strengthen exchanges and cooperation with international high-level journalism schools or news media groups, learn their advanced journalism concepts and teaching management models, broaden their horizons, and focus on cultivating students' global vision, which is more conducive to cultivating elites with international perspectives in journalism and communication and to improve their practical business levels. Rich practical experience and perception of news are the advantages of these industry talents, which are also urgently needed for talents of journalism and communication in Chinese universities.

Of course, the introduction of talents in the industry must have corresponding policy supporting guarantees: there should be supporting measures such as income stability and professional title evaluation. The resolution of these problems requires the vigorous advancement of various departments of society and schools, and should also arouse the attention of education departments. Colleges and universities should "incentivize young teachers to come to the media, and to vividly perceive the essence and key of media operations. Even if the talents introduced from the industry should return to the media after three to five years, they should always be at the forefront of media practice" (Zheng, 2017). In this way, the training of talents journalism and communication can enter a virtuous circle.

\section{Cultivate Interdisciplinary Journalism Talents}

Experts and scholars discuss "converged media", they talk more about technology integration, and less about other aspects of integration. To train truly expert journalists, "you must use your brains on cross-faculty and cross-professional cooperation, and carry out the allocation and optimization of educational resources at a higher level" (Qing et al., 2020). However, this problem is more complex and difficult. Journalism and communication education in China is basically a single education. After graduating from high school, students go to university and spend more than two to three years studying journalism and communication knowledge, that is, "Journalism" professional courses, while knowledge of other subjects is relatively lacking, such as economy, law, sports, information, materials, biotechnology, ocean, etc. It is indeed difficult for students majoring in journalism and communication with a rich knowledge structure to write well on "economics", "nanomaterials" and other reports. In this regard, American journalism and communication education can be worth learning from. For example, in the School of Journalism at the University of Missouri in the United States, the first two years of the undergraduate degree are mainly to consolidate the students' humanities foundation, and then learn professional knowledge in the next few years, which will help students master more comprehensive humanities knowledge. The " $2+2$ " model implemented by the School of 
Journalism of Fudan University in China can be said to be an inspiration from the journalism education of the University of Missouri. This training mode is the first and second year of undergraduate. Students can choose one direction from the economics, sociology, Chinese language and literature, electronic information science and technology, and plan to study according to the above four directions; in the third and fourth academic year, study in accordance with the training plan of each major of journalism and communication. In four years, students requested to master the undergraduate professional knowledge of two subjects. The trained students become "complex talents" and "expert reporters".

Therefore, the author reckons that whether Chinese four-year undergraduate talents of journalism and communication can be cultivated in this way: by "examination" or admitting directly some students who are interested in journalism and communication in the second half of the sophomore or third year of the junior year. After one year to one and a half years of practical training in journalism, journalism students will improve their professional ethics and knowledge. These training courses should be conducted in real media. In this way, practical training upon completion, students will naturally participate in the media or related media work. Colleges and universities have tried this, and the effect is obvious.

For example, the "Journalism Experimental Class" set up by College of Media, Guizhou Minzu University in China is to conduct a second enrollment selection examination for students from all majors of the school one year after entering the school. And students who are interested in journalism and communication are selected through the two links of written examination and interview., which can be called the " $1+3$ " model of the reform of journalism and communication education. However, compared with the " $2+2$ " model of the School of Journalism of Fudan University, I believe that the latter one is more capable of cultivating "expert" talents with a solid foundation, but the large-scale selection method of Guizhou Minzu University is more conducive to the cultivation of "compound talents with strong practical ability" (Qian, 2019). If the two can be combined for reference, it may be a new training model exploration. After graduation, these students will be able to achieve "zero distance" employment without spending a lot of time on pre-job training.

\section{Strengthen Practical Training to Improve Students' Operational Ability}

In addition to theoretical curriculum education, journalism and communication education should pay more attention to practical teaching, and can learn from the "Missouri Method" (Shen \& Zhao, 2018). In the course of practice, "professionals of journalism and communication" should always remind themselves that they are "news people" to play the "role" well and get ramped up quickly, and strive to increase their self-adjustment capabilities. By cooperating with the media industry to build a broader training and internship platform playing a 
practical role for students to participate in. In the era of media convergence, "there is a greater demand for cross-category and cross-boundary talents." Journalism and communication talents with proficient skills are required. Being able to perform practical operations is naturally an important feature of talent training in this major. To improve students' operational ability, college newspapers, radio stations, networks, television and other news propaganda departments are good practice bases. Universities can set up campus news centers "central kitchen" under the unified leadership of the Publicity Department of University Party Committee. All departments should be integrated with each other. "The news center has four business departments: an office, an interview department, a newspaper and network editorial department, and a radio and television editorial department" (Zhang, 2020) in order to use news materials reasonably and efficiently, and then adopt the principle of "collect once, use $\mathrm{N}$ times", put the collected materials into the news element database, and each department can process and disseminate as needed. In this way, through the integration training of various media forms, students will be exposed to various styles of newspapers, radio, television, Internet, mobile phones and other media during the internship process, and then become "all-rounders" and "all reporters". Colleges and universities can also cooperate with Internet media groups, newspaper groups, radio and television groups or media companies to train “order-type" students. The students' assignments are connected and submitted to the real media, which is equivalent to students' internship in the media. "Colleges of Journalism should introduce a mechanism to jointly build with mainstream news organizations and cutting-edge technology companies, so that more news teaching can be carried out in a simulated media environment to cultivate students' practical ability" (Huang, 2017).

News websites, newspaper groups, radio and television groups or enterprises will naturally become the best platform for student internship training, which is conducive to student reporters' in-depth understanding of the concept of media convergence, and also lays a solid foundation for their future careers.

\section{Conclusion}

To sum up, as the integration of Chinese media continues to deepen, the structure and pattern of knowledge innovation in the field of Chinese journalism and communication are being reshaped. It challenges colleges of journalism and communication, at the same time, it also provides rare opportunities for the development. The series of reforms, innovations and practical explorations carried out by Chinese universities around media convergence will promote new and better development of the education of Chinese journalism and communication, which is an inevitable trend and we will wait and see.

\section{Conflicts of Interest}

The author declares no conflicts of interest regarding the publication of this paper. 


\section{References}

Bai, J. (2020). Reform and Innovation of News Practice Teaching under the Background of Media Convergence (pp. 30-36). News and Writing.

Chen, Z. P. (2013). Effective Ways to Cultivate the Professional Spirit of Students Majoring in Journalism and Communication: Practice and Thinking of "Ziniu Cup" Social Investigation Activities. Modern Communication, 6, 132-134.

Guoke, et al. (2006). The Enlightenment and Suggestions of American Evaluation System of Journalism Education to China. Chinese Journal of Journalism \& Communication, 12, 26-30.

He, M. H. (2017). An Analysis on the Revision of the Accreditation Standards for National Journalism and Communication Education. Modern Communication, 10, 148-154.

Huang, H. Z. (2017). Current Situation, Problems and Suggestions of Journalism and Communication Education in Universities of Hunan. News Front, 4, 38-40.

Qi, S., \& Zhao, L. M. (2018). Proceed Cautiously: Research on the Status Quo of Data Journalism and Communication Talent Cultivation in the United States: Based on the Empirical Analysis of 100 Journalism Colleges and Universities of Association for Education in Journalism and Mass Communication(ACEJMC). Journalism Review, 2, 39-45.

Qian, G. (2019). How to Solve the "Last Kilometer" of Journalism Teaching: An Exploration of the Innovative Practice Teaching Mode of Guizhou Minzu University. New Observation of Media Integration, 4, 75-76.

Qiang, Y. X., et al. (2020). Cultivation of Journalism and Communication Talents from the Perspective of Arts. Chinese Editorials, 10, 58-64.

Tang, T. T., \& Zhen, R. (2017). Research on the Innovation of Journalism and Communication Talents Training Model and Teaching Reform: Based on the Background of Big Data. Journal of Southwest JiaoTong University (Social Science), 18, 8-14.

Wang, Z. P. (2018). “Three-Span" and "Four-Way": The New Dimension of Journalism and Communication Education in the Era of Mobile Internet. China Publishing Journal, 8, 51-54.

Yin, Y.Y., \& Zhang, H. (2020). Reform and Exploration of the Training Mode of Journalism and Communication Talents in Local Colleges and Universities in the Digital Media Era: A Case Study of Yichun University. Communication and Copyright, 8, 175-177.

Zhang, T. (2020). Journalism Education of University in the Age of Media Convergence: Challenges and Countermeasures. Journal of Zhejiang Sci-Tech University (Social Science), 44, 100-108.

Zheng, Y. N. (2017). The Transformation of the Faculty Is the Key to the Reform of Media Convergence Education: Also on the Reform and Practice of Media Convergence Education in Heilongjiang University. Media, 21, 24-25. 